\title{
The Implementation of Bobanehena Tourism Village Development in West Halmahera Regency
}

\author{
Saiful Deni ${ }^{1}$, Thamrin Husain ${ }^{1}$, Anggriyani Salaka ${ }^{1}$, Zubair Saing ${ }^{1}$ \\ ${ }^{1}$ Universitas Muhammadiyah Maluku Utara, Ternate 97716, Indonesia \\ *Corresponding author. Email: zubairsaing@ummu.ac.id
}

\begin{abstract}
The study's purpose was to analyse how the Indonesian village and tourism ministry cooperative agreement executed. The analysis method uses qualitative descriptive. Data obtained from interviews and documentation. Implementation criteria using Edward III theory that is; communication, resources, disposition, and bureaucratic structure. The results found that there was excellent communication between central, regional, and village governments. Besides, the Bobanehena society support who warmly welcomed the tourism development program in their village, and the most crucial thing is sufficient funding sources in tourism developing process supporting facilities. Meanwhile, there is a positive attitude that supports implementation success. Following, the fulfilment of standard operation procedure (SOP) by Bobanehena tourist village from the central government. The tourist village's development through community empowerment, increasing tourist visits number, destination development using attractions, amenities and visible accessibility, and growing people income.
\end{abstract}

Keywords: Bobanehena, village, tourism

\section{INTRODUCTION}

The tourism sector is one of the country's most critical foreign exchanges, and sources can contribute national economy significantly, such as employment absorption [1][3]. Modern tourism products now abandoned. Tourists are turning to tourism products that value the environment, nature, culture, and attractions in a particular way [4]-[6]. Tourist satisfaction does not only rely on the natural beauty and the tourist completeness facilities but also the interaction flexibility and intensity with the environment and local communities. One strategy that thrives and becomes a stakeholder is the strategy for developing community-based tourism villages.

Rural tourism is undoubtedly different from urban tourism both in terms of object, location, function, scale, and character, which certainly have consequences for planning and development [7]-[9]. Rural tourism development in Indonesia developed through Tourism Village. Tourism Village is a suitable model in community empowerment programs based on local value wisdom. The tourist village's development in Indonesia is growing and developing well, until 2017, Indonesia has 1,302 tourist villages spread across various islands in Indonesia. The most tourist villages owned by the islands of Java, Bali, and Sumatera. The tourist village's existence provides a solution to the local community's economic prosperity, opens employment opportunities, and raises regional income [10], [11].

With internal encouragement, such as the economic and social impact arising from the tourist village's development, supported by external incentives, such as changes in the tourist's motivation who want to be able to interact directly with local communities [12], [13], With these two impulses, the cooperates of Village and Tourism Ministry to empower rural communities by providing capital support and ideas in developing tourism villages. The village fund's existence has rolled out since the Jokowi government offered an excellent opportunity for rural communities to use village funds to develop village potential [14]-[17]. The village ministry's policy of $10 \%$ of village funds is devoted to rural tourism development. Thus, a government policy is taken in the event of tourist villages, such as in the Memorandum of Understanding Tourism and Village Minister No: NK.13/KS.001/MP/2016 and No: 10/MDPDTT/KB/XII/2016 in Tourism Village Development. Which was then followed up in a Cooperation Agreement between the Deputy of Destination and Tourism Industry Development, the Ministry of Tourism with the Directorate General of Development and Empowerment of Village Communities, Ministry of Village on Tourism Village Development through Village Community Development and Empowerment No: 87/KS.001/DPDIP/KEMPAR/2017 and No: 009/DPPMD/PKS/IV/2017, which aims to increase the number of domestic and foreign tourists and efforts to move the economy to improve the welfare of rural communities. West Halmahera Regency is one of the districts in North Maluku that makes tourism villages a tourism potential [18]. There are so many natural, cultural, and sustainable social potentials in communities that need to develop. On May 9, 2015, the Tourism Office of West Halmahera Regency formed ten tourism villages and was followed by seven preparatory tourist villages so that the number of tourist villages in West Halmahera was 17 tourist villages with each potential owned. Therefore, Bobanehena tourist village is one of the communities that experienced rapid development. 
Bobanehena Village is one village has established of West Halmahera Regency Government as a Tourism Village. Some of the main attractions in Bobanehena Tourism Village are beach, houses on the sea, agro, spice, local cultural and religious attractions. Tourism Village is different from other tourist attractions because the community itself carries out all activities. The whole life and daily life of the local people, along with the village location natural settings are inside the village area, allowing tourists to interact as active participants. The Bobanehena tourist village development involved all local communities, thus providing a significant impact. This community involvement can be seen from the beginning of the establishment to the tourist facilities construction at the local community initiative, especially the youth and the government support.

However, this does not necessarily turn out to be a tourist village that has a tourist attraction as it is today, but through several processes that must be fought for where initially there was resistance from parents who refused to develop tourist villages in Bobanehena due to foreign cultures fear that will affect their perception. The difficulties in land acquisition from privately owned land into local government because the purchase is an absolute requirement that must be met to get assistance from the central government. Besides, there are also community leaders who refuse village funds use in local government facilities construction at the location; these matters indeed become a polemic for village officials and conscious tourism groups in tourism development. However, with high enthusiasm, they continued to struggle, the approach to the community was even more intensely carried out to change the community mindset about tourism itself, so this was fruitful both with the increase in tourism supporting facilities such as cottages, lighting, and other amenities, as well as the number of visits tourists who keep increasing.

\section{METHOD}

The study used the descriptive qualitative method, where describes systematically about a particular situation and program [19]-[21]. The study was conducted in Bobanehena tourist village West Halmahera Regency. In the village, the government role and community participation in tourism villages management explored in the development of community-based tourism villages. From the tourist village, it includes several tourist attractions as well as supporting tourism infrastructure facilities located around the tourist village. There are two data sources used, that is primary and secondary data sources. Primary data sources include data obtained directly from the source through interviews and in-depth observations. In this case, the primary data collected from critical respondents provides information from the Head of the Tourism Office of West Halmahera Regency, Head of the Community Empowerment and Village Government Service and local communities who directly participate in the management of tourist villages such as village heads, leader's community, tourism village manager (Tourism Awareness Group), and visiting tourists.
Primary and secondary data is collected from the source and explores the phenomena that occur in the communities of the two villages. Based on data obtained from crucial information interviewed, individual notes made, tabulations, and syntheses were subsequently carried out using qualitative descriptive analysis with linking answers obtained from local communities, both Bobanehena village community leaders who knew and understood various related issues with development in this tourist village. The respondent's selection and determination based on the discussions results with the head of the relevant tourism village. Moreover, other information sources are from government officials who are related to the object. Informants are significant people because all information wants to obtain in the informants who are selected to ask for information the data they want to achieve used as the basis for completing this study. Therefore, in determining the informant, some considerations need, such as; 1) personal knowledge and experience of the information collected; 2) the person concerned as an informant is the indigenous community figure in the sense that the community is born and lives in the village; 3 ) in terms of age in the mind that the person concerned has understood the problems studied and is physically and mentally healthy.

In-depth interview data collection techniques, purposive sampling, and sample techniques were adopted using snow bowling methods, where studies used their knowledge to determine who were the most appropriate sources to include in the study. By basing on the potential of information and knowledge possessed by speakers who match the relevant criteria, then interviewing respondents is conducted and focused on the problems under study. Although this study is limited to Bobanehena tourism village, the selection of suitable sources is not natural because appropriate sources are needed and have specific and comprehensive knowledge of the object under study, which only a small proportion of respondents, such as tourism agents, communities, village management staff tourism, NGOs, and the government.

Criteria were chosen, respondents and resource persons must be members of the tourism village management team (chairman or coordinator) and visitors to the tourism village and related OPDs. The resource person must have been actively participating or involved in the activities of the tourist village since the beginning of the formation of tourist villages and directly involved in management. This criterion is essential to ensure that the interviewee can provide appropriate answers to the situation of the town, and can provide an analysis of the involvement, constraints, and strategies of community-based village development. The purposive sampling technique is considered to be the most effective way of selecting key individuals to be interviewed. Regarding the number of respondents taken following the name is not determined, but based on the adequacy of the information obtained. Based on the data collected, since the observations made, the data has been analyzed or interpreted. However, the results obtained must be explored and synthesized, resulting in new propositions and conclusions. This step is carried out after making data reduction. Phenomena that occur in the community investigated. Validity is the data accuracy that happens in the study object using a triangulation validity test. In this study, data obtained from primary and secondary then 
checked the truth with observation and documentation results.

\section{RESULTS AND DISCUSSION}

Administratively, Bobanehena Village included in the Jailolo capital district, West Halmahera Regency, with $5 \mathrm{~km}$ distance from district government center, and Jailolo port is around $1 \mathrm{~km}$. Bobanehena village consists of three residents and nine neighborhoods with an area of $1000 \mathrm{Ha}$, as shown in Figure 1. The topography of Bobanehena Village, about 26 to 100 meters above sea level, belongs to the highlands. The temperature of $24-35{ }^{\circ} \mathrm{C}$. The soil type in this area, mostly andisol soil is quite high sensitivity erosion, its various acidity, and low organic matter. Accessibility to the capital city has been an excellent hot-mix road, even though the hamlet access is still partially constructed. Most of the Bobabeneha people are farmers. Farming in Bobanehena Village divided into spice plantation commodities such as nutmeg, clove and coconut, and horticulture crops such as banana and rambutan. The most widely planted types of forestry commodities are pine, while the most farmed products are coconut, cloves, and nutmeg. This forestry type and plantation commodity have a rotation of more than one year.

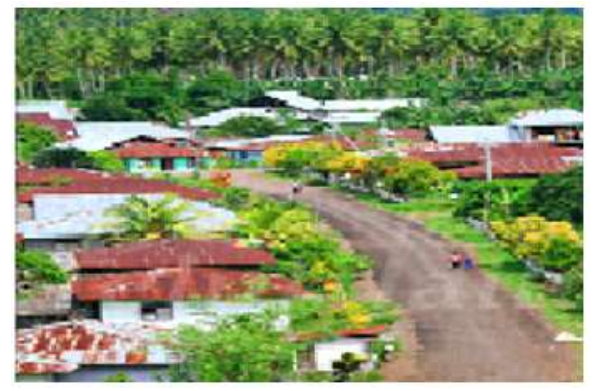

Figure 1 Bobanehena village

\subsection{Bobanehena Village Tourist Attraction and Potentially}

The tourist attraction is anything that has the uniqueness, value, and convenience in natural, cultural, and humanmade diversity that motivates tourists to visit. Bobanehena Tourism Village is one tourist village that has different and unique potential and tourist attractions. The uniqueness tourist attractions because it departs from the people's habits, customs, and local resistance.

\subsubsection{Natural tourism}

As one village has mountains and sea areas, it gives its color in the tourists' eyes. Bobanehena village has a natural tourist attraction, culture, and special interests. The local community that manages natural tourism is Rappa Pelangi Beach. The distance traveled from the city center is 15 minutes using two-wheeled vehicles, four-wheeled vehicles, and city transportation services called bentor. Snorkeling activities with relatively calm waves and entirely different underwater wealth. Besides, play other water rides such as a banana boat, or to swim even exercise can be done there and enjoy the beautiful natural scenery while enjoying ginger (aer guraka) and fried banana.

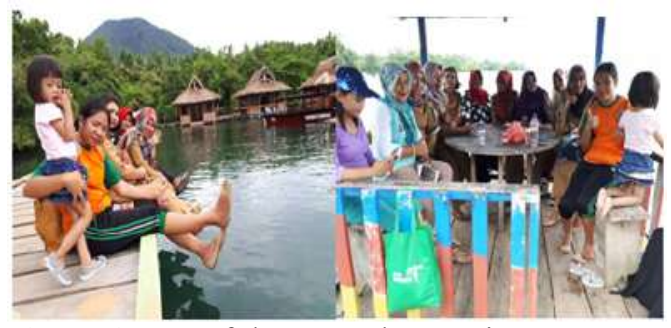

Figure 2 One of the natural attractions

\subsubsection{Culture Tourism}

The cultural tourist attraction is a developed tourist attraction based on the work and results of human creation, both in heritage and values cultural still alive in society, which forms of ceremonies/rituals, customs, performing arts, craft arts, literature and fine arts [22], [23]. Tourist destinations in Bobanehena Village included cultural tourism attractions are religious tourism, Kololi Dehe ritual, Nurul Hidayah Mosque (which is in the process of development), and Denge-denge music. Indonesia As one of the largest Islamic countries in the world, it is undoubtedly very potential if religious tourism developed. This Muslim tourist market potential is seen by Bobanehena tourism managers and must form as a tourist attraction. Religious tourism developed by a conscious travel group (Pokdarwis) with the Bobanehena Village community. The development and dynamics of the people majority Bobanehena Village are Muslims known for their high religiosity. So the idea of religious tourism is that tourists can feel the spiritual atmosphere in this village. In the North Maluku community, rituals development often heard and known are the kololi kie and lufu kie rituals from Ternate, and the fere kie ritual of Tidore. Kololi Dehe is one West Halmahera rituals that developed in Bobanehena Village. Besides the ngolo singofi ritual carried out by the Jailolo Sultanate, Kololi Dehe has been encouraged as a tourist attraction and is in high demand by tourists.

\subsubsection{Special Interest Tourism}

Bobanehena village offers tourism concept with experiences that travelers have never had before. Attractions are born from history combination and local habits of the local community. Spice tourism wants to rebuild how the diversity of spices in North Maluku is an integral part of Indonesian history. These spices attracted Portuguese to come to colonize and master the spices. Maleo birds, which are endemic birds from Sulawesi, found in Bobanehena Village, only Maleo birds in this village have overall black feathers; there are no white elements on their feathers like those found in Sulawesi. 


\subsection{Development of Bobanehena Tourism Village}

At present, Indonesia has three leading sectors developed, namely agriculture, fisheries, and tourism. The community of Bobanehena is a note of agrarian society. People who make agriculture their main livelihood. Besides, as an archipelago, fishers become the next pillar of life. So, before the entry of tourism, the people of Bobanehena Village did not have group activities outside the harvest period. The harvest period for nutmeg and coconut is usually every six months, while for 1-2 year clove plants.

In 2014, the youth of Bobanehena Village, who were members of the Bobanehena Village Youth Forum, initiated the Coastal Culture Festival. The festival concept is to introduce cultures that exist in Jailolo coastal region. Besides, there are sea-related competitions such as fishing and swimming. All villages on the Jailolo coast are involved in this festival. The economy at that time began to run because some Jailolo communities also sell snacks and drinks during the festival. Even though the target audience in this festival is still within the scope of local tourists, the spirit of the youth of Bobanehena Village to develop tourism in the region increasingly built. After the successful implementation of the Coastal Culture Festival, the youth of Bobanehena Village proposed to the Government to hold similar events with the Coastal Culture Festival, which aims to introduce the cultures that exist in Bobanehena Village. The local government has responded, but there has been no implementation in the field. In early 2015, the West Halmahera Tourism Office offered a budget for developing community-based tourism villages for ten villages that have tourism potential in the Jailolo region, and one of them is Bobanehena Village.

Using the budget and coupled with community self-help, the youth worked together to build a 112-meter long bridge as access to the beach and beachside gazebos as a place to relax the tourists later. Then the beach was named Rappa Pelangi Beach. After the construction, Rappa Pelangi Beach began to be visited by many tourists, both local and outside the area. With the development of tourism in Bobanehena Village, Pokdarwis form, which sheltered by the West Halmahera Tourism Office as a place for Bobanehena Village communities to channel their ideas related to tourism development in the region.

\subsection{Development of Community Based Bobanehena Tourism Village}

In globalization current era, tourism has become a separate lifestyle for the wider community [24][25]. Based on the necessities of life, tourism is the second human needs category that needs, but in the globalization era, where tourism information increasingly accessible to the broader community, tourism must improve. As stated in Indonesia Law No. 10/2009 concerning Tourism, explained the understanding of tourism, especially the overall activities related to tourism and multi-dimensional/multidisciplinary in nature that emerge as a manifestation of every person need and country as well as interactions between tourists and local communities, fellow tourists, the Government, Regional Government and entrepreneurs.

In the global-local context, tourists visiting a region, it is possible to bring their respective cultures from various parts of the world into the local community's culture. The local community must have a strategy of how the multiple cultures brought by tourists, do not pose a culture threat the local community has held firm. Based on the observations during the field trip, tourist interaction with the local community was quite good. Local people can adequately accept outside tourists who visit warmly as long as they do not violate the norm. When there are tourists who dress that are not following local customs, the community will admonish them well, so that there is no conflict in tourism activities.

From interviews results, tourists visiting Bobanehena Village not as a threat as though by the elderly, but the entry of tourists for them is an opportunity. Not only for economic activities, but also for cultural preservation and norms embedded, because the entry of tourists, the public will be prouder to introduce and demonstrate their culture, so that becomes a form of cultural preservation.

Tourists who follow the Kololi Dehe ritual are also taught by the community to respect their ancestors when they are going to do activities in Bobanehena Village. Based on the observations, the religious and traditional characteristics of the Bobanehena Village community can be positive in community-based tourism development in this village. The community will have a stronger principle and establishment so that they have held firmly are not easily damaged by outsiders. Besides, the existence of tourism, the community is better at protecting its environment, especially beaches. Currently, in Bobanehena village, Pokdarwis members routinely hold safeguards to anticipate the presence of fish shooters that have the potential to damage underwater wealth.

\subsection{Implementation of Government Policy in Bobanehena Tourism Village Development through Community Development and Empowerment}

Independence and innovation realize if supported by the tourism village's development. Through the tourism village's development, rural, mainly rural communities that have the potential for attraction nature and culture, given insights on tourism, are given the ability to take the potential advantage and attractiveness of their villages. Potential and tourist attractions are built using village funds. So that the two ministries support each other to succeed in village program and invasion towards the tourist village, in 2017 , the deputy of tourism destination and industry development in the department of tourism and the directorate general of village community development and empowerment at the ministry of village, development of disadvantaged regions and transmigration entered into a cooperation agreement on developing rural tourism through the development and empowerment of village communities with No: PK.87 / KS.001 / DPDIP / KEMENPAR / 2017 and No: 009 / DPPMD / PKS / IV / 2017. 
The implementation of tourism development from the ministry of tourism, ministry of village PDTT even stakeholders, through the development and empowerment of rural communities, are as follows; 1) The tourism village development program to increase and has full support from the central government, in this case, the ministry of tourism; 2) The construction of cottage facilities built by West Halmahera public works agency in 2017. However, the development did not count as one package but only built cottage houses without any facilities inside. It is a challenge for the management of tourist villages because the five cottages cannot utilize if there are no facilities such as mattresses, tables, chairs, and other facilities in the cabin. In 2018 BRI on March 19 visited Bobanehena Village and saw the tourist attractions that dominate directly, then to follow up the visit, BRI Bank assists IDR. 458.1 Million to facilities in cottages to be used by tourists; 3) Follow up on Law No. 6/2014 on Villages and Regulation of the Village Minister of PDTT No. 1/2015 concerning authority guidelines based on origin and village-scale local authority, village-owned business entity (BUMDES) was formed in various villages in Indonesia, one of which was BUMDES in Bobanehena Village. The establishment of the BUMDES in Bobanehena was named the Tarakan Bobanehena BUMDES in 2016. After the establishment of the Tarakan Bumdes, all village economic development programs were directed and in line with the interests of improving the tourism village economy; 4) Rappa Pelangi Beach is dark at night because there are no lighting lamps available for the road, either from the Bobanehena Village road to the Rappa Pelangi Beach destination but no street lights yet. Seeing the shortcomings in the destination area, the Ministry of Village of PDTT assists in 2018 a package of public lighting facilities at 7 points and the construction of a homestay worth IDR. 200 Million; 5) The provision of homestay assistance following the category of tourists. The funding source was from village funds in 2018. However, it necessary to manage corporations through BUMDES so that the construction of this homestay has an economic impact on villages that have that potential.

\subsection{Implementation Analysis of Collaborative Agreements between Tourism and Village PDTT Ministry in Bobanehena Tourism Village Development}

\subsubsection{Communication}

Communication policy means a process of delivering policy information from policymakers to implementers [26][27]. Consists of three dimensions that strongly support the success of policy implementation that is, transmission (transformed to implementers), clarity (clarity related to the substance of public policy to be achieved effectively and efficiently), and consistency [28][29]. Following up on the agreement, the Ministry of Village of PDTT and the Ministry of Tourism coordinated with the local government, and they also went directly to several tourist villages in West Halmahera to review it directly. From the review of the tourist village, Bobanehena chose as a tourist village that would assist because it fulfilled the conditions set by the Ministry, it was all based on technical guidelines. The effectiveness and accuracy in the selection of villages to choose to develop. The Ministry of Village directly to the local government of West Halmahera Regency, in this case, the Department of Tourism and DPMPD to communicate related to the request of appropriate village data to get assistance in developing tourism villages to obtain accurate data. Communication, in this case, takes place intensely and well, between the center, the region, and the village.
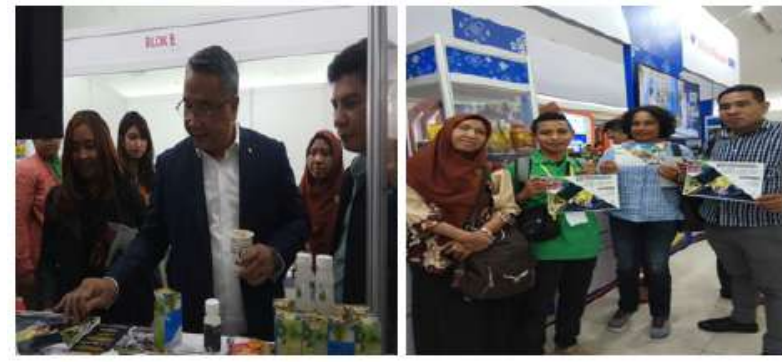

Figure 3 The village-owned business entity (Tarakan BUMDES)

The better communication coordination of the parties involved in the implementation process will achieve success and to avoid mistakes that will occur, and policy delivery do apparently. Besides, the central government does not only coordinate with the tourism office but also with the community empowerment service and the village government concerning launching a complete process. Because of the excellent communication between the village government and conscious tourism groups, whereas a driver of tourism in the village, they are always intensely communicating with related agencies, and they are informing transformations where they already know what to do, and the clarity of information accepted. Consistent given by the government, they have prepared land acquisition from the start. Other tourist villages have not moved, while the village of Bobanehena has been making for a long time, so when funding gives, they are the ones who deserve it. Do not forget that the regional government is an extension of the central government.

\subsubsection{Resources}

Resources mean human, budget, equipment, information, and authority. Human resources in Bobanehena tourist village is the role of Youth who is active in supporting all government programs, then the existence of Pokdarwis, which tourism driver, besides the village government very forward-thinking for the progress. The process of developing the Bobanehena tourist village looks a step ahead of other tourist villages. Their sense of optimism, enthusiasm without knowing the challenges, obstacles, and continued to move forward. Therefore, implementation effectively cause by humans is an essential resource in determining implementation success. Besides, the application in the development process will not succeed without the support of sufficient funding sources. The 
source of funds or budget from the government has been realized, not only from the central government but also from the local government, especially the tourism office, one of which is the establishment of Pokdarwis, where the tourism agency funds the legality.

Equipment resources where the facilities used for operational policy implementation, one of which island, is one of the supporting activities for effective implementation because if individuals own the land, implementation will not work effectively, there will be conflict. However, tourist sites in Bobanehena are government-owned land, which has also equipped with infrastructure supporting tourism. The authority resources, even though the government side, but intended for community empowerment where the community as the implementing policy.

\subsubsection{Dispositions}

To effectively implementation, the implementer not only knows what to do but must have the desire. Therefore, the Bobanehena community also has the existence of unity from the community to carry out government programs. They worked together to clean up the location, even participate in the process. The attitude of the Bobanehena community is perfect and has positive thoughts also related to tourism development. Therefore, the implementers' attitudes or tendencies significantly affected the successful implementation process, but the community well received in the development process. It can see from the fact in the field that they jointly contribute to the success of government programs. From a community attitude that strongly supports the process of developing tourism, it will also have a good impact; the budget does come from not only the regional government but also the central government.

\subsubsection{Bureaucratic structure}

Even though the public knows what to do, it can fail to cause a lack of bureaucratic structure. In April 2018, the Ministry of Tourism visited West Halmahera and visited tourist villages that were successful in utilizing village funds. There are several tourist villages visited by Guaria, Bobanehena, and Tuada. Because various ministry programs require complicated prerequisites to be fulfilled by other tourist villages, one of them is the destination land owned by the local government, and this is an obstacle for other communities, including Tuada Village and Guaria Village.

The result found that there was good cooperation between the government and the Bobanehena villagers so that the program could run well. It has proved where they have fulfilled the four variables described by George Edward III [30], that is, communication, resources, disposition, and bureaucratic structure [31]. First, they build excellent communication between them, then with the regional and central government. Second, they have resources that have thoughts and desires that want to move forward and develop as well as supporting budgetary resources. Third, the attitude of accepting them for government policies that actively support government programs, and the fourth is that they fulfil the SOP given. Furthermore, from the results of interviews with several visitors, it can conclude that there is an increase in Bobanehena tourism village development, the increasing number of tourist visits, tourism supporting infrastructure facilities that have to see from attractions, amenities, and accessibility and economy increase.

\section{CONCLUSION}

Bobanehena Tourism Village is one of the tourist villages in West Halmahera, which is experiencing rapid development. The existence can see it as infrastructure facilities in tourist locations support, the presence of gazebos, and other public spaces. Besides, the number of tourists visiting continues to grow, and the community economy-level much better, for example, mothers can sell at tourist sites, and residents' houses can use as homestays. This progress supports the involvement of all parties, including the community, village government, regency, center, and even the private sector. Therefore, agreement Implementation between Tourism and Village PDTT Ministry in tourist village Bobanehena developing runs effectively and successfully because they fulfill four variables proposed by George Edward III that is communication, resources, disposition, and bureaucratic structure without them knowing and realizing.

\section{REFERENCES}

[1] C. Von Luebke, N. McCulloch, and A. A. Patunru, "Heterodox reform symbioses: the political economy of investment climate reforms in Solo, Indonesia," Asian Economic Journal, vol. 23, no. 3, pp. 269-296, 2009.

[2] A. A. Patunru, N. McCulloch, and C. Von Luebke, "A Tale of Two Cities: The Political Economy of Local Investment Climate in Solo and Manado, Indonesia," 338, 2009.

[3] R. Bahramitash, "Islamic fundamentalism, and women's employment in Indonesia," International Journal of Politics, Culture, and Society, vol. 16, no. 2, pp. 255-272, 2002.

[4] Z. Liu, "Sustainable tourism development: A critique," Journal of sustainable tourism, vol. 11, no. 6 , pp. 459-475, 2003.

[5] J. Briedenhann and E. Wickens, "Tourism routes as a tool for the economic development of rural areasvibrant hope or impossible dream?," Tourism Management, vol. 25, no. 1, pp. 71-79, 2004.

[6] R. C. Lois-González and X. M. Santos, “Tourists and pilgrims on their way to Santiago. Motives, Caminos, and final destinations," Journal of Tourism and Cultural Change, vol. 13, no. 2, pp. 149-164, 2015. 
[18] T. Husain, H. Akib, H. A. Gani, and M. Guntur, "Colaboración del actor en la formulación del programa de desarrollo del destino turístico en West Halmahera Regency (Indonesia)," Revista Espacios, vol. 39, no. 44, p. 27, 2018.

[19] P. Baxter and S. Jack, "Qualitative case study methodology: Study design and implementation for novice studies.," 2008.

[20] J. W. Creswell and J. D. Creswell, Study design: Qualitative, quantitative, and mixed methods approach. Sage publications, 2017.

[21] N. K. Denzin and Y. S. Lincoln, The qualitative inquiry reader. Sage publications, 2002.

[22] D. J. Timothy, Cultural heritage and tourism: An introduction, 4th ed. Channel View Publications, 2011.

[23] I. M. Azmi, The tragedy of the commons: commercialization of cultural heritage in Malaysia, 2nd ed. 2012. Intellectual property law and the politics of scale in Indonesian arts," American Ethnologist, vol. 35, no. 4, p. 607-631., 2008.

[12] A. Spiteri and S. K. Nepalz, "Incentive-based conservation programs in developing countries: a review of some critical issues and suggestions for improvements," Environmental Management, vol. 37, no. 1, p. 1-14., 2006.

[13] B. Bramwell and L. Alletorp, "Attitudes in the Danish tourism industry to the roles of business and government in sustainable tourism," International Journal of Tourism Study, vol. 3, no. 2, p. 91-103., 2001.

[14] H. Antlöv, A. Wetterberg, and L. Dharmawan, "Village governance, community life, and the 2014 village law in Indonesia," Bulletin of Indonesian Economic Studies, vol. 52, no. 2, pp. 161-183, 2016.

[15] J. McCarthy and M. Sumarto, "Distributional Politics and Social Protection in Indonesia: Dilemma of Layering, Nesting, and Social Fit in Jokowi's Poverty Policy," Journal of Southeast Asian Economies, vol. 35, no. 2, pp. 223-236, 2018.

[16] R. Shrestha and I. Coxhead, "Can Indonesia Secure a Development Dividend from Its Resource Export Boom?," Bulletin of Indonesian Economic Studies, vol. 54, no. 1, p. 1-24., 2018.

[17] Z. R. Anderson, K. Kusters, J. McCarthy, and K. Obidzinski, "Green growth rhetoric versus reality: Insights from Indonesia," Global Environmental Change, vol. 38, p. 30-40., 2016.
[24] S. Milne and I. Ateljevic, "Tourism, economic development, and the global-local nexus: theory embracing complexity," Tourism Geographies, vol. 3, no. 4, p. 369-393., 2001.

[25] E. Cohen and S. A. Cohen, "Current sociological theories and issues in tourism," Annals of Tourism Study, vol. 39, no. 4, pp. 2177-2202, 2012.

[26] W. N. Dunn, Public policy analysis. Routledge, 2015.

[27] D. Stone, "Transfer agents and global networks in the "trans-nationalization of policy," Journal of European public policy, vol. 11, no. 3, p. 545-566., 2004.

[28] M. Hill and P. Hupe, Implementing public policy: An introduction to the study of operational governance. Sage, 2014.

[29] S. Milio, From policy to implementation in the European Union: the challenge of a multi-level governance system, 13th ed. IB Tauris., 2014.

[30] C. E. George, Implementing public policy. Congressional Quarterly Press, 1980.

[31] S. Deni, J. Rasai, and Z. Saing, "Public policy analysis on disaster threat due to geo-environmental condition of Tugurara River in Ternate City, North Maluku Province," International Journal of GEOMATE, vol. 17, no. 60, pp. 211-218, 2019. 